\title{
Phytochemical screening, cytotoxicity and anti-inflammatory activities of the Zimbabwean endemic plant P hyllanthus serpentinicola Radd.-Sm. (Phyllanthaceae)
}

\author{
C. Zimudzi, L.F.Gwenhure, N.Kunonga, S. Kativu and J. Jere \\ Department of biological Sciences, University of Zimbabwe, P.O. Box MP 167, Mt Pleasant, Harare, Zimbabwe.
}

\author{
ARTICLE INFO \\ Article history: \\ Received on: 10/10/2012 \\ Accepted on: 21/10/2012 \\ Available online: 28/10/2012

\section{Key words:} \\ Phyllanthus serpentinicola, \\ phytochemicals, cytotoxicity, \\ BSL bioassay, anti- \\ inflammation
}

\begin{abstract}
Stem methanolic extract of Phyllanthus serpentinicola was screened for phytochemicals, and tested for cytotoxicity and anti-inflammatory activities. Tests indicated presence of alkaloids, tannins, terpenoids, reducing sugars and flavonoids. Saponins, anthraquinones, and cardiac glycosides were absent. Cytotoxic effects of the plant were assessed through Brine shrimp lethality (BSL) bioassay. An $\mathrm{LC}_{50}$ value of $1.3 \mu \mathrm{g} / \mathrm{ml}$ was found, thus indicating that the stem extract was strongly cytotoxic. Anti-inflammatory activity was assessed by the egg albumen induced hind paw oedema test on Swiss albino mice. The extract significantly $(\mathrm{p}<0.05)$ reduced the oedema, thus indicating that $P$. serpentinicola has anti-inflammatory properties.
\end{abstract}

\section{INTRODUCTION}

Genus Phyllanthus belongs to family Phyllanthaceae, a recent segregate of Euphorbiaceae sensu lato. The genus is widely represented in tropical and subtropical regions of the world. Thirty nine species have been recorded in Zimbabwe, with one, Phyllanthus serpentinicola, being endemic to the country (Radcliff-Smith, 1996).

The species is restricted to the serpentine soils of the Great Dyke area of the country. P. serpentinicola is a suffrutex, up to $30 \mathrm{~cm}$ high, with spirally arranged, simple, obovate leaves which bear inconspicuous flowers in leaf axils. Male flowers are solitary and yellowish green, whilst female flowers are dull green, often pinkish tinged, and form a disk with broad rounded lobes. Phytochemical and pharmacological

* Corresponding Author

C. Zimudzi, Department of biological Sciences, University of Zimbabwe, P. O. Box MP 167, Mt Pleasant, Harare, Zimbabwe.

Telephone: +263-4-772669975, Fax: +263-4-333407 evaluation of several Phyllanthus species has identified a number of useful biologically active compounds. Phyllanthimide, an alkaloid used as a model for the synthesis of cystostatic agents in treatment of cancer is one of several useful compounds derived from Phyllanthus (Calixto et al., 1998). Phyllanthus species reportedly have antipyretic, analgesic, anti-inflammatory, antihepatotoxic and antiviral activities (Unander et al., 1990). Phytochemical and pharmacological profiles of Phyllanthus show variability according to species and environmental conditions (Calixto et al., 1998).

In southern Africa, Phyllanthus species are used to treat a variety of ailments including arthritis, bronchitis, earache, sore eyes, swollen gums, burns and wounds (Bosch, 2008). P. serpentinicola has never been phytochemically evaluated nor tested for its cytotoxicity or anti-inflammatory activities. The present study evaluates the phytochemical composition of the species and at the same time tests its anti-inflammation and cytotoxic activities. 


\section{MATERIAL AND METHODS}

\section{Collection of plant material}

Fresh stems of $P$. serpentinicola were collected from Mutorashanga Pass along the Great Dyke of Zimbabwe in January 2012. The plant was identified in situ. Voucher specimens are deposited at the University of Zimbabwe teaching herbarium. Freshly collected stems were washed in tap water and air-dried for two weeks.

\section{Crude extraction}

Dried stems were chopped into pieces and milled into a fine powder by pounding manually with a clean pestle and mortar. Some $2 \mathrm{~g}$ of ground material was extracted with $100 \mathrm{ml}$ analytical grade methanol as solvent at room temperature for $48 \mathrm{~h}$ using the cold maceration method.

The extract was filtered using Whatman filter paper (No: 1), concentrated and evaporated to dryness in vacuo at $40^{\circ} \mathrm{C}$ using a rotary evaporator. The powder extract was re-dissolved in distilled water and stored in a refrigerator at $4{ }^{\circ} \mathrm{C}$.

\section{Phytochemical screening}

Standard qualitative methods as described by Sowofora (1993) and Tiwari et. al (2011) were adopted for phytochemical screening. The crude extract was tested for phytochemical constituents using the following tests and reagents: reducing sugars with Fehlings test, anthraquinones with Borntragor's test, terpenoids with Salkowski test, flavonoids with ammonia and suphuric acid, saponins with foam test, tannins with Ferric Chloride test, alkaloids with Mayer's and Draggendorff's tests and cardiac glycosides with Keller- Killian's test.

\section{Brine shrimp lethality test}

The cytotoxicity activity of the crude extract was assessed on brine shrimp nauplii (Artemia salina) according to brine shrimp lethality bioassay (Meyer et al., 1982). Artificial sea water was prepared by dissolving $12 \mathrm{~g}$ sodium chloride in $1 \mathrm{~L}$ of distilled water and adjusting the $\mathrm{pH}$ to 8.5 using $40 \%$ sodium hydroxide. Some $2 \mathrm{~g}$ of brine shrimp eggs were hatched in $1 \mathrm{~L}$ of sterile sea water in a flask. The cysts were kept under bright light, and were continuously agitated and aerated using an aquarium pump. The nauplii hatched within $48 \mathrm{~h}$ at room temperature.

The methanol crude extract was dissolved in $1 \%$ aqueous dimethyl sulfoxide (DMSO) in artificial sea water to obtain concentrations of extract varying from $100 \mathrm{mg} / \mathrm{ml}$ to $0.25 \mathrm{mg} / \mathrm{ml}$. Some $50 \mu \mathrm{l}$ of each solution was transferred, to clean sterile vials containing $5 \mathrm{ml}$ of aerated seawater. Ten shrimp nauplii were transferred to each vial. The experiments were performed in triplicate for each extract concentration. Potassium dichromate $(5 \mathrm{mg} / \mathrm{ml})$ and $1 \%$ DMSO in seawater were used as positive and negative controls, respectively. After $24 \mathrm{~h}$, the vials were examined against a lighted background using a hand held magnifying glass, and the number of nauplii that survived in each vial were counted.
Evaluation of anti-inflammatory activity Animals

Adult Swiss albino mice of both sexes were used for these experiments. They were obtained from the Animal House at Central Veterinary Laboratories in Harare, Zimbabwe. The animals were housed in cages, and were allowed free access to standard pellets and water. All procedures used in the study comply with guidelines on animal care provided by the University of Zimbabwe Ethics Committee on the use of animals.

\section{Anti-Inflammatory Test}

The test was carried out using a phlogistic agent induced mouse hind paw oedema as a model of acute inflammation (Winter et al, 1962). Fresh egg albumen was used as the phlogistic agent. Adult Swiss albino mice of either sex were fasted for $14 \mathrm{~h}$ and then divided into 5 groups of six mice each. Each group received a different treatment. The extract $(100,200$ and $300 \mathrm{mg} / \mathrm{kg}$ ) was administered intra-peritoneally using a syringe $1 \mathrm{~h}$ before inducing inflammation. The negative control group received $10 \mathrm{ml} / \mathrm{kg}$ distilled water and the positive control $100 \mathrm{mg} / \mathrm{kg}$ of Acetic salicylic acid (ASA). Inflammation was induced by injection of $0.1 \mathrm{ml}$ of fresh egg albumen into the subplantar surface of the right hind paw of the mice. Paw oedema was measured by wrapping a piece of cotton thread round the paw and measuring the circumference with a ruler (Okokon et al., 2012). The measures were determined at 1,2 and $3 \mathrm{~h}$ following egg albumen injection.

\section{Data analysis}

Results were analyzed using Microsoft Excel statistical package (2007). Cytoxicity data were analysed using linear regression analysis. All values were expressed as mean \pm SEM. A one-way ANOVA was applied to determine the significance of the difference between the control groups and mice treated with the extracts. A Student's t-test was used to compare the treatments and controls, and results were considered significant when $\mathrm{p}<0.05$.

\section{RESULTS AND DISCUSSION}

\section{Phytochemical Screening}

Table 1 shows the results of the phytochemical screening. The extract tested positive for alkaloids, tannins, terpenoids, reducing sugars and flavonoids, and negative for saponins, anthraquinones, and cardiac glycosides. The observed phytochemical profile of $P$. serpentinicola is similar to that of other Phyllanthus species (Calixto et al., 1998).

Screening for phytochemicals in plants is important as a first step in elucidating the pharmacological properties of a plant species. The phytochemicals identified in $P$. serpentinicola belong to large diverse groups with varied pharmacological activities. Alkaloids are known to exhibit anti-inflammatory, cytotoxic antibacterial, analgesic and anti cancer activities (Roberts and Wink, 1998). Flavonoids and tannins are phenolic compounds that are known to have antimicrobial, anti-inflammatory, cytotoxic, 
antiallergic, analgesic and antioxidant properties (Cowan, 1999). Terpenoids are reported to have anti-inflammatory, anti cancer, antimalarial and antibacterial properties (Govindappa et al., 2011).

Table 1. Results of phytochemical screening tests on methanol extract of $P$. serpentinicola

\begin{tabular}{ll}
\hline Test & Observation \\
\hline Alkaloids & + \\
Cardiac Glycosides & - \\
Tannins & + \\
Anthraquinones & - \\
Terpenoids & + \\
Saponins & - \\
Reducing sugars & + \\
Flavonoids & + \\
\hline
\end{tabular}

Key $-=$ absent and $+=$ present

Table 2. Effect of stem methanolic extract of P.serpentinicola on fresh egg albumen-induced inflammation in mice (means $\pm \mathrm{SD}, \mathrm{n}=6, * p<0.05$ ).

\begin{tabular}{|c|c|c|c|c|}
\hline \multirow[t]{2}{*}{ Treatment } & \multirow{2}{*}{$\begin{array}{c}\text { Dose(m } \\
\text { g/kg) }\end{array}$} & \multicolumn{3}{|c|}{ Paw Oedema $(\mathrm{cm})$} \\
\hline & & $1 \mathrm{~h}$ & $2 \mathrm{~h}$ & $3 \mathbf{h}$ \\
\hline $\begin{array}{l}\text { Distilled } \\
\text { water }\end{array}$ & $10 \mathrm{ml} / \mathrm{kg}$ & $1.47 \pm 0.12$ & $1.58 \pm 0.08$ & $1.73 \pm 0.15$ \\
\hline PSE & 100 & $1.90 \pm 0.13 *$ & $1.81 \pm 0.1 *$ & $1.77 \pm 0.10$ \\
\hline PSE & 200 & $1.87 \pm 0.08 *$ & $1.76 \pm 0.09^{*}$ & $1.68 \pm 0.073$ \\
\hline PSE & 300 & $1.85 \pm 1.17 *$ & $1.72 \pm 0.14 *$ & $1.62 \pm 0.13$ \\
\hline ASA & 100 & $1.95 \pm 0.04 *$ & $1.86 \pm 0.07 *$ & $1.79 \pm 0.06$ \\
\hline
\end{tabular}

\section{Brine shrimp lethality test}

The brine shrimp mortality was $100 \%$ in the Potassium dichromate standard and in all extract concentrations above $8 \mu \mathrm{g}$ $/ \mathrm{ml}$. These data have been excluded from Figure 1 which shows the mean percent mortality of the brine shrimp nauplii against the logarithm of the sample concentrations. The mortality of brine shrimps increased with increasing concentration of extract. The regression equation on Figure 1 was used to calculate an $\mathrm{LC}_{50}$ value of $1.3 \mu \mathrm{g} / \mathrm{ml}$.

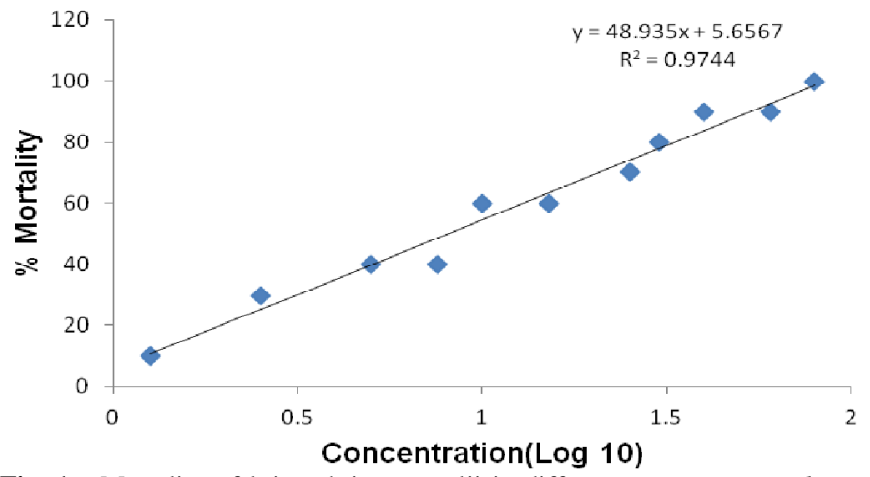

Fig. 1: Mortality of brine shrimp nauplii in different $P$. serpentinicola stem extract concentrations.

Standard brine shrimp lethality bioassay stipulates that $\mathrm{LC}_{50}$ values less than $1000 \mu \mathrm{g} / \mathrm{ml}$ are considered bioactive in toxicity evaluation of plant extracts (Meyer et al., 1982). Based on this benchmark, the $P$. serpentinicola extract is strongly cytotoxic since the $\mathrm{LC}_{50}$ value was less than $1000 \mu \mathrm{g} / \mathrm{ml}$. Cytotoxicity of the extract is attributed to presence of alkaloids, tannins, flavonoids and terpenoids ( Sandhar et al., 2011). The $\mathrm{LC}_{50}$ value of $1.3 \mu \mathrm{g} / \mathrm{ml}$ for $P$. serpentinicola is comparable to that for Phyllanthus engleri $(0.47 \mu \mathrm{g} / \mathrm{ml})$ where cytotoxicity has been attributed to presence of triterpenoid phyllanthol (Bosch, 2008). P. engleri is a poison plant commonly encountered in suicide cases in Zimbabwe (Bosch, 2008). Thus, care should be exercised in using $P$. serpentinicola as a medicinal plant.

\section{Anti-inflammation activity}

Egg albumen induced oedema is a widely accepted model for the evaluation of anti-inflammatory effect of plant extracts. Table 2 shows the activity of $P$. serpentinicola extract against egg albumen induced paw oedema in mice. Control mice produced a local hind paw oedema that increased progressively throughout the three hour period. Pretreatment by $P$. serpentinicola extract significantly $(\mathrm{p}<0.05)$ reduced the oedema in the first two hours, but no significant differences between the treatments and control were observed after three hours ( $p>0.05)$. The standard showed a similar pattern to the treatments. Egg albumen inflammation is biphasic, and the high anti-inflammatory activity of the extract may be a response to the initial acute phase of inflammation. The first phase occurs within two hours of administering the phlogistic agent, and is due to the release of histamine or serotonin, and the second phase of oedema is due to the release of prostaglandin (Oyekunle and Idowu, 2012). Results of the present study indicate that the methanol extracts of $P$. serpentinicola significantly reduced paw oedema in mice. The anti-inflammatory mechanism of action may be due to blocking of the release of these chemical mediators.

The anti-inflammatory activity $P$. serpentinicola is attributed to the phytochemical constituents of the plant extract which include terpenoids, tannins, flavonoids and alkaloids. Plants containing these chemical classes of compounds have been reported to possess potent anti-inflammatory properties that act through inhibiting prostaglandin pathways (Oyekunle and Idowu, 2012).

\section{CONCLUSIONS}

The present study has demonstrated that stem methanolic extract of $P$. serpentinicola exhibits anti-inflammatory and cytotoxicity activities. Caution should; however, be exercised in the use of this species for medicinal purposes because of its high toxicity as evidenced by the $\mathrm{LC}_{50}$ values of $1.3 \mu \mathrm{g} / \mathrm{ml}$. The results also suggest that the plant contains bioactive constituents that are responsible for the observed activities. The results from this study suggest that $P$. serpentinicola like other Phyllanthus species can be useful for the management of pain.

\section{ACKNOWLEDGEMENTS}

The authors acknowledge the Department of Biological Sciences, University of Zimbabwe, for providing its laboratory facilities for this study. The Chief technician, Gerald Ashley, and his technical staff provided invaluable technical assistance. 


\section{REFERENCES}

Bosch C.H. (2008). Phyllanthus engleri. In G.H. Schmelzer \& A. Gurib-Fakim (Ed.). Plant Resources of Tropical Africa 11(1). Medininal Plants 1. Leiden: Backhuys Publishers.

Calixto J.B., Santos A.R., Cechinel V. F., Yunes R.A. A review of the plants of the genus Phyllanthus: their chemistry, pharmacology, and therapeutic potential. Med. Res. Rev. 1998; 18(4): 225-258.

Cowan M.M. Plant products as antimicrobial agents. Clin. Microbiol. Rev.1999; 12: 564-582.

Govindappa M., Naga S.S., Poojashri M. N., Sadananda T. S. Chandrappa C. P. Antimicrobial, antioxidant and in vitro antiinflammatory activity of ethanol extract and active phytochemical screening of Wedelia trilobata (L.) Hitchc. Journal of Pharmacognosy and Phytotherapy. 2011;3(3): 43-51.

Meyer B.N., Ferrigni N.R., Putnam J.E., Jacobsen L.B., Nichols D.E., Mc Lauglin J.L. Brine shrimp: a convenient general bioassay for active plant constituents. Planta Med. 1982; 45: 31-34.

Okokon J. E. Antia B. S. Ita B.N. Anti-Inflammatory and Antinociceptive Effects of Ethanolic Extract of Setaria megaphylla Leaves in Rodents. Afric. J. Biomed. Res. 2006; 9: 229-233.

Oyekunle A.O., Idowu A.O. Anti-inflammatory activity of methanolic extract of Cnidoscolous aconitifolius leaves in laboratory rodents. Journal of Chemical, Biological and Physical Sciences.2012; 2(2): 770-774.

Radcliff-Smith A. Euphorbiaceae. Flora Zambesiaca.1996; 9(4):
Roberts M.F., Wink M. Alkaloids: Biochemistry, ecology and medicinal applications. ; Plenum, New York, 1998.

Sandhar H.K., Kumar B., Prasher S., Tiwari P., Salhan M., Sharma P. A Review of Phytochemistry and Pharmacology of Flavonoids. Internationale Pharmaceutica Sciencia. 2011; 1(1):25-41.

Sofowora E.A. Phytochemical Assays in "Medicinal Plants and Traditional Medicine in Africa". Third edition. Spectrum Books Limited, Abuja. (1993) 150-153.

Tiwari P., Kumar B., Kaur M., Kaur G., Kaur H. Phytochemical screening and Extraction: A Review. Internationale Pharmaceutica Sciencia. 2011; 1 (1): 98-106.

Unander D.W., Webster D.W., Blumberg B.S. Record of usage or assays in Phyllanthus (Euphorbiaceae) I. Subgenera Isocladus, Kirganelia, Cicca and Emblica. J. Ethnopharmacol. 1993; 30: 233-264.

Winter C.A., Risley E.A. Nuss G.W. Carragenin induced oedema in hind paw of the rats as an assay of anti-inflammatory drugs. Proceedings of the Society for Experimental Biology and Medicine. 1962; 111: 544-547.

\section{How to cite this article:}

C. Zimudzi, L.F.Gwenhure, N.Kunonga, S. Kativu and J. Jere. Phytochemical screening, cytotoxicity and anti-inflammatory activities of the Zimbabwean endemic plant Phyllanthus serpentinicola Radcl.-Sm. (Phyllanthaceae). J App Pharm Sci. 2012; 2 (10): 050-053. 